\title{
Optical Chemical Sensor for Screening Cadmium(II) in Natural Waters
}

\author{
Yadamari Tharakeswar, Yakkala Kalyan, Battala Gangadhar, Korivi Sujan Kumar, \\ Gurijala Ramakrishna Naidu* \\ Department of Environmental Sciences, Sri Venkateswara University, Tirupati, India \\ Email: "naidugrk@yahoo.com
}

Received December 23, 2011; revised January 19, 2012; accepted January 29, 2012

\begin{abstract}
Membrane based optical chemical sensor (optode) for $\mathrm{Cd}(\mathrm{II})$ was developed by the immobilization of a dye 1-(2-Pyridylazo)-2-Napthol (PAN) in the Tri-(2-Ethylhexyl) Phosphate (TEHP) plasticized Cellulose Triacetate (CTA) matrix. Various combinations of PAN immobilized in the cellulose triacetate CTA and Polystyrene (PS) matrices plasticized with Tri-(2-Ethylhexyl) Phosphate TEHP, 2-Nitrophenyl Octyl Ether (NPOE) and Dioctyl Phthalate (DOP) were studied to arrive a suitable composition and found that the optode does not require any extractant to produce a distinct colour change on complexation with $\mathrm{Cd}(\mathrm{II})$. On sorption of $\mathrm{Cd}(\mathrm{II})$ in the optode matrix, PAN changes color of the optode from golden yellow to violet red having a maximum absorbance $\left(\lambda_{\max }=553 \mathrm{~nm}\right)$ within $150 \mathrm{~min}$ of total equilibration time at $\mathrm{pH}=7.5$. The optode developed in the present work was studied for its analytical application for $\mathrm{Cd}(\mathrm{II})$ in the aqueous samples by spectrophotometry and as well as Flame Atomic Absorption Spectrophotometry (FAAS). This preconcentrated optode showed a linear response by UV-visible spectrophotometry at $\lambda_{\max }=553 \mathrm{~nm}$ over a concentration range of $10 \mathrm{ng} \cdot \mathrm{mL}^{-1}$ to $500 \mathrm{ng} \cdot \mathrm{mL}^{-1}$ of $\mathrm{Cd}$ (II) ions. Where as the aqueous solutions was also subjected to FAAS before and after equilibration of the optode and found to be linear in the concentration range of $250 \mathrm{ng} \cdot \mathrm{mL}^{-1}$ to 5000 $\mathrm{ng} \cdot \mathrm{mL}^{-1}$ of $\mathrm{Cd}(\mathrm{II})$ ions. The optode found to be reversible and can be desorbed by equilibrating it with $0.01 \mathrm{~mol} \cdot \mathrm{L}^{-1}$ $\mathrm{HNO}_{3}$. The applicability of the developed optode in real samples was studied by determining cadmium in the natural waters spiked with a known amount of $\mathrm{Cd}(\mathrm{II})$ ions.
\end{abstract}

Keywords: Optode; Cd(II) Ions; 1-(2-Pyridylazo)-2-Napthol (PAN); FAAS

\section{Introduction}

The large-scale production of a variety of chemical compounds has led to increased discharge of chemicals that causes the global deterioration of the environmental quality. Among the released chemicals, heavy metals are highly toxic and cause serious threat to human and the environment $[1,2]$. In various toxic metal ions, cadmium (II) is one of the common contaminants which gains due to its high toxic nature even at very low concentrations and it has been recognized as one of the most toxic environmental and industrial contaminants due to its ability to induce severe alterations in various organs and tissues following either acute or chronic exposure [3-6]. According to EPA the permissible limit of cadmium in drinking water is $0.05 \mathrm{mg} / \mathrm{L}$ [7]. The tolerance limits for cadmium in potable water are usually between 5 and 10 $\mathrm{mg} / \mathrm{L}$ and a threshold limit value of $0.05 \mathrm{mg} \cdot \mathrm{m}^{-3}$ for cadmium dust and cadmium salts in workplace atmospheres has been suggested [8]. There are many analytical

${ }^{*}$ Corresponding author. methods that can be used for the quantification of $\mathrm{Cd}(\mathrm{II})$ in different environmental matrices, in which various preconcentration procedures including conventional liquid-liquid extraction, solid phase extraction based on adsorption or ion exchange, cloud point extraction, electroanalytical techniques etc., have been used $[9,10]$. Optical chemical sensors (optodes) for metal ions detection have found increasing applications over the past several years. These are generally associated with such advantages as simplicity and low cost as well as suitability for remote and continuous monitoring. Optodes for metal ion determination can be fabricated by employing different types of reagents such as chromogenic, fluorescent and ionophoric compounds and enzymes [11]. To improve the analytical signal, preconcentration by several orders of magnitude enhances the accuracy of the results, offer a high degree of selectivity and facilitates calibration. Optodes offer a possibility of simultaneous preconcentration and quantification of a target analyte with a minimum sample manipulation, reasonable selectivity and improved sensitivity without using any reference devices [12]. 
Optical sensors for $\mathrm{Cd}(\mathrm{II})$ ions in the aqueous samples have been developed using various strategies [13-17]. Ensafi et al. have developed optical chemical sensor using 2-Amino-Cyclopentene-1-Dithiocarboxylic Acid (ACDA) on a cellulose triacetate membrane for sensing $\mathrm{Cd}$ (II) ions in the ground water samples. Sanchez-Pedren et al., three kinetic methods based on flow injection, flow, and stopped-flow injection was applied for the determination of $\mathrm{Cd}(\mathrm{II})$ using an optode membrane that incorporates 1-(2-Pyridylazo)-2-Naphtol (PAN) in a plasticized poly (vinyl) chloride. Czolk et al. have developed optic-chemical sensor (optode) for the detection of heavy metal ions using 5,10,15,20-tetra( $p$-sulfonatophenyl) porphyrin covalently immobilized onto a polymeric matrix, complexation of ions, such as $\mathrm{Cd}(\mathrm{II}), \mathrm{Pb}$ (II) or $\mathrm{Hg}$ (II) [18]. An optical-fiber chemical sensor (optode) have developed for determination of $\mathrm{Zn}$ (II) and $\mathrm{Cd}(\mathrm{II})$ mixtures using 2-(5-bromo-2-pyridylazo)-5-(diethylamino)phenol immobilized onto XAD-4 (Br-PADAP/XAD-4) by Kuswandi $\mathrm{B}$ et al. [19]. Rezaei, B. et al. have developed optode using 1,2-bis(quinoline-2-carboxamido)-4-chloro-benzene $\left(\mathrm{H}_{2} \mathrm{Clbqb}\right)$ as an excellent ionophore in the construction of a cadmium (II)-selective PVC-based membrane sensor [20]. In all the above proposed methods optode membranes required either extractants of ionophores but at the same time membrane shows slow response.

In the present work, a simple colour changeable optode was developed for the determination of ultra-trace levels of cadmium. This was prepared by the immo-bilization of a chromophore 1-(2-Pyridylazo)-2-Naphtol (PAN) in the Tri-(2-Ethylhexyl) Phosphate (TEHP) plasticized Cellulose Triacetate (CTA) matrix. The optode developed in the present work was studied for its analytical application for $\mathrm{Cd}(\mathrm{II})$ in the aqueous samples by spectrophotometry and as well as Flame Atomic Absorption Spectrophotometry (FAAS).

\section{Experimental}

\subsection{Materials and Apparatus}

Analytical reagent grade cadmium chloride, sodium hydroxide, dichloromethane, chloroform and 1-(2-Pyridylazo)-2-Naphtol (PAN) were obtained from Merck (Mumbai, India). Double distilled water was used throughout the present work. Cellulose triacetate molecular weight $72,000-74,000$ acetyl value $+43.2 \%$ from sigma Aldrich (Steinheim, Switzerland) from Fisher scientific (Hong Kong), Polystyrene (PS) from the Acros Organics (Geel, Belgium), Tri-(2-Ethylhexyl) Phosphate (TEHP) from koch-light laboratories (Coinbrook Bucks, England), 2-Nitrophenyl Octyl Ether (NPOE) from Sigma-Aldrich (Steinheim, Germany) and Dioctyl Phthalate (DOP) from the British Drug Houses Ltd. (Poole, England) were used. The $\mathrm{pH}$ of the solution was carried out with Elico LI120 pH meter from Elico Lab, Hyderabad. UV-visible spec- trophotometer model UV-1800 from Shimadzu (Japan), was used for recording the absorbance spectra. Flame Atomic Absorption Spectrometry (Perkin-Elmer, Model 2380, USA) with single and multi-elemental hallow cathode lamps of cadmium element was employed in the studies. The $\mathrm{pH}$ of the sample was prepared with using $0.01 \mathrm{M}$ of $\mathrm{HCl}$ and $0.01 \mathrm{M}$ of $\mathrm{NaOH}$ solution. The natural water samples were collected from the surrounding of rural and industrial areas of Tirupati, Chittoor District, A.P., India.

\subsection{Optode Preparation}

Cellulose Triacetate (CTA) of 0.2 grams was dissolved in $10 \mathrm{~mL}$ of dichloromethane. An amount of 0.001 grams of 1-(2-Pyridylazo)-2-Naphtol (PAN) and 0.1 grams of Tri(2-Ethylhexyl) Phosphate (TEHP) was dissolved in 10 $\mathrm{mL}$ of chloroform separately. Both the solutions were mixed and ultrasonicated for $2 \mathrm{~min}$ to form a homogeneous casting solution. The casting solutions were spread on a Petri dish (internal diameter of $9 \mathrm{~cm}$ ) kept on a levelled surface. After two days, the membrane was casted with controlled evaporation of the dichloromethane, the transparent optode was peeled off from Petri dish using water. The optode thus prepared was thoroughly washed with distilled water to remove soluble components. The optode samples were cut in the size of $2 \mathrm{~cm} \times 1 \mathrm{~cm}$ and the same size optode was used through the experiment. The chemical structure of Cellulose Triacetate (CTA), Tri-(2-Ethylhexyl) Phosphate (TEHP) and 1-(2-Pyridylazo)-2-Naphtol (PAN) are shown in Scheme 1.

\subsection{Measurement Procedure}

The optode with the immobilized PAN was cut into $2 \mathrm{~cm}$

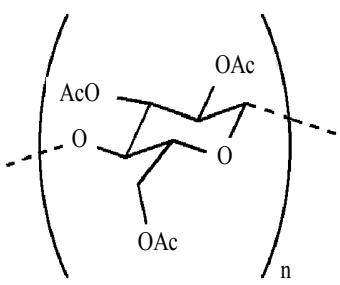

Cellulose Triacetate

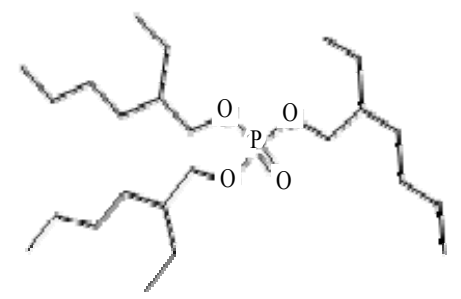

Tri-(2-Ethylhexyl) Phosphate (TEHP)

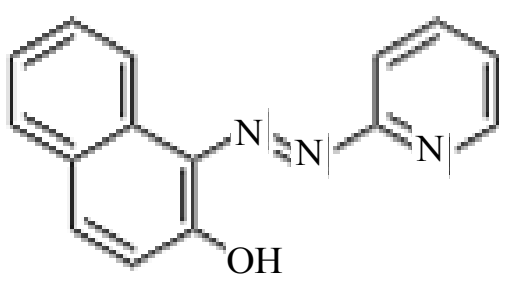

1-(2-Pyridylazo)-2-Naphtol

Scheme 1. Structures of the components used in the preparation of the optode. 
$\times 1 \mathrm{~cm}$ dimension and placed vertically inside the cuvette and the intensity was measured spectrophotometrically at $\lambda_{\max }=466$ and this was treated as blank. The same optode was sorbed with $\mathrm{Cd}(\mathrm{II})$ solution at $\mathrm{pH}=7.5$ for about $150 \mathrm{~min}$ and the intensity of Cd(II)-PAN complex formed in the optode sample as a function of cadmium concentration in the equilibrating solution was studied spectrophotometrically. The optode was scanned for the optimum $\mathrm{pH}$ for the sorption of $\mathrm{Cd}(\mathrm{II})$ at various $\mathrm{pH}$ ranging from 2 to 9 . The equilibrating solutions of $25 \mathrm{~mL}$ were maintained at $\mathrm{pH}=7.5$ using $0.01 \mathrm{M} \mathrm{NaOH}$ solution and known amounts of $\mathrm{Cd}(\mathrm{II})$ ions ranging from 10 $\mathrm{ng} / \mathrm{mL}$ to $5000 \mathrm{ng} / \mathrm{mL}$ were added. The sorption of $\mathrm{Cd}^{2+}$ ions in the optode samples was recorded at $\lambda_{\max }=553$ corresponding to PAN-Cd ${ }^{2+}$ complex formed in the optode matrix. The $\mathrm{Cd}(\mathrm{II})$ contents were measured according to the calibration graph, produced by the same procedure for different concentrations of $\mathrm{Cd}(\mathrm{II})$ ions.

The kinetic studies of optode $(2 \mathrm{~cm} \times 1 \mathrm{~cm})$ was equilibrated in a solution of known concentrations of $\mathrm{Cd}(\mathrm{II})$ $(500 \mathrm{ng} / \mathrm{mL}, 2000 \mathrm{ng} / \mathrm{mL}$ and $5000 \mathrm{ng} / \mathrm{mL})$ ions at $\mathrm{pH}=$ 7.5. The optode sample was taken out of the equilibration solution for every $5 \mathrm{~min}$ time interval, and the absorbance was measured at $553 \mathrm{~nm}$. This was continued till a constant absorbance value was obtained.

The desorption studies of $\mathrm{Cd}(\mathrm{II})$ was studied by equilibrating the optode sample in well stirred $25 \mathrm{~mL}$ of 0.01 $\mathrm{mol} \cdot \mathrm{L}^{-1} \mathrm{HNO}_{3}$ aqueous solution. The absorbance reading was taken for every $5 \mathrm{~min}$ till the optode is completely reversible.

\subsection{Cadmium Uptake Studies Optode by FAAS}

The uptake studies of cadmium ion in the optode was also studied by using the flame atomic absorption technique. For uptake studies of $\mathrm{Cd}(\mathrm{II})$, known amount of cadmium ion was spiked in $25 \mathrm{~mL}$ of aqueous solution at $\mathrm{pH}=7.5$ using $0.01 \mathrm{~mol} \cdot \mathrm{L}^{-1} \mathrm{NaOH}$. The optode sample $(2 \mathrm{~cm} \times 1 \mathrm{~cm})$ was completely equilibrated for a period of $150 \mathrm{~min}$. The uptake percentage of $\mathrm{Cd}(\mathrm{II})$ by the optode was measured by FAAS making use of before and after equilibrated sample solutions. The percentage of uptake of Cd(II) ions in the optode was calculated by the following equation:

$$
\text { Uptake } \%=\frac{\left(\mathrm{A}_{\text {before }}-\mathrm{A}_{\text {after }}\right)}{\left(\mathrm{A}_{\text {before }}\right)} \times 100
$$

where $A_{\text {before }}$ and $A_{\text {after }}$ are the absorbance of Cd(II) ions in the sample taken from before and after equilibrated sample solutions respectively.

\subsection{Application to Real Samples}

The developed procedure was used for the quantification and determination of $\mathrm{Cd}(\mathrm{II})$ ions in the natural water samples by comparison of the absorbance of the optode at $553 \mathrm{~nm}$ with the calibration curve. The optode was equilibrated in natural water sample $(25 \mathrm{~mL})$ spiked with known amount of $\mathrm{Cd}(\mathrm{II})$ for $150 \mathrm{~min}$ at $\mathrm{pH}=7.5$. The optode sample was washed thoroughly with the deionized water and its absorbance was measured at $553 \mathrm{~nm}$ against air or blank optode sample.

\subsection{Interference Studies}

The interference of foreign ions like $\mathrm{SO}_{4}^{2-}, \mathrm{PO}_{4}^{3-}, \mathrm{Na}^{+}$, $\mathrm{Ca}^{2+}, \mathrm{Fe}^{3+}, \mathrm{Cr}^{3+}$, EDTA, $\mathrm{Mn}^{2+}$ and $\mathrm{Ni}^{2+}$ was studied by preparing $0.01 \mathrm{~mol} \cdot \mathrm{L}^{-1}$ of respective solutions. The optode $2 \mathrm{~cm} \times 1 \mathrm{~cm}$ area optode samples was equilibrated with each interfering ion for $150 \mathrm{~min}$ at $\mathrm{pH}=7.5$ and spectra was recorded.

\section{Results and Discussion}

PAN is known to be terdentate ligand for metal ions and various divalent cations like $\mathrm{Zn}(\mathrm{II}), \mathrm{Cd}(\mathrm{II}), \mathrm{Hg}(\mathrm{II})$ and $\mathrm{Cu}$ (II) forms a coloured complex with PAN in the $\mathrm{pH}$ range of 7 - 10.5 [1,21,22]. The 1-(2-Pyridylazo)-2Naphtol (PAN) immobilized on the surface of Cellulose Triacetate (CTA), acts as a selective optical sensor for $\mathrm{Cd}(\mathrm{II})$ ion at $\mathrm{pH}$ 7.5. The metal complexation with PAN optode is due to its phenolic rings leaving the hydrophilic moieties (oxygen and azo-nitrogens) available for metal complexation through the formation of one or even two coordination spheres leading to the respective stable five-member rings $[21,22]$. It may be assumed that 1:2 $\mathrm{Cd}(\mathrm{II})-\mathrm{PAN}$ complex is formed in the optode membrane, since this was the stoichiometry found in a non-aqueous solution for the Cd(II)-PAN complex. The reaction between the $\mathrm{Cd}(\mathrm{II})$ present in the aqueous phase and the optode membrane and the subsequent regeneration of the membrane is shown in Scheme 2.

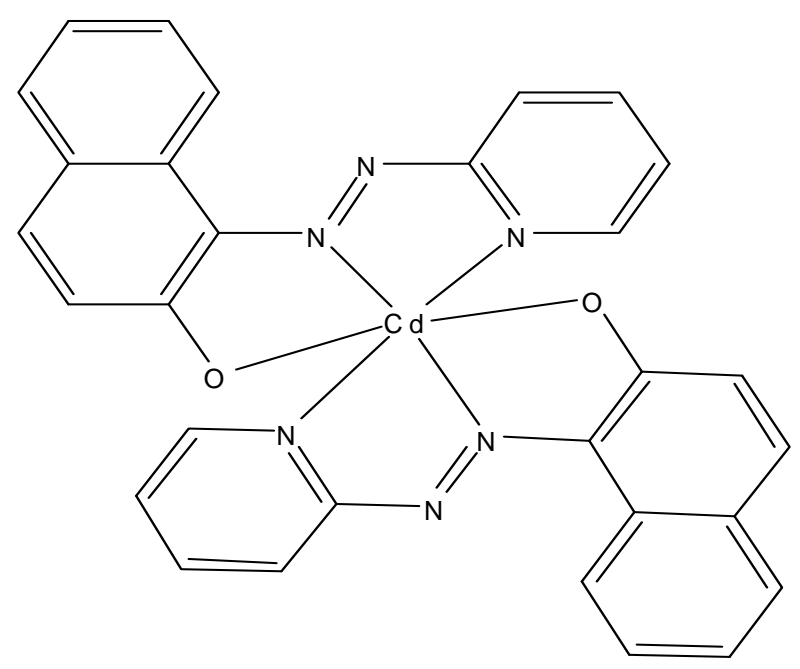

Scheme 2. Chemical structure of Cd(II)-PAN complex. 


\subsection{Optimization Studies}

In the present work, PAN immobilized in a cellulose triacetate plasticized with tri-(2-ethylhexyl) phosphate, was found to produce colour change on equilibration in aqueous solution containing $\mathrm{Cd}$ (II) ions in $\mathrm{pH}$ 7.5. It was observed that there was no colour change of optode, if PAN is immobilized along with some extractants like Bis (2-ethylhexyl) phosphoric acid (HDEHP), dibromo-pxylene (DBPX) and trioctylmethylammonium chloride (Aliquat-336). It indicates that the developed optode doest not require any extractant which is contrary to our previous work [12]. The proportions of CTA and TEHP in the optode were optimized in terms of better uptake, kinetics, mechanical strength and uniformity. The optimized composition of the optode was found to be: CTA $=0.2 \mathrm{~g}, \mathrm{TEHP}=0.1 \mathrm{~g}, \mathrm{PAN}=0.001 \mathrm{~g}$.

\subsection{Effect of $\mathbf{p H}$}

The $\mathrm{pH}$ of the test solution plays a vital role in deriving sensor performance. The influence of $\mathrm{pH}$ on the Cd-PAN optode response has been studied by varying $\mathrm{pH}$ ranges from 2 to 9 . The sorption of $\mathrm{Cd}(\mathrm{II})$ ion was found to be maximum at the $\mathrm{pH}=7.5$. The optimization of $\mathrm{pH}$ studies was shown in Figure 1. The decrease in percentage sorption at $\mathrm{pH}<7.0$ is due to the insufficient formation of the Cd-PAN complex. Hence, in subsequent studies, the $\mathrm{pH}$ was adjusted to 7.5 using dil. $\mathrm{NaOH}$.

\subsection{Dynamic Response Time}

Dynamic response time is an another important analytical factor that measures the sensing ability of the membrane optode. The response time was recorded by equilibrating the optode membrane with a well-stirred solution containing known concentration of Cd(II) ions in $25 \mathrm{~mL}$ by adjusting the $\mathrm{pH}=7.5$. The absorbance of optode was measured at $\lambda_{\max }=553$, absorbance was measured for every 5 minutes time interval and it was continued up to 150 minutes till a constant absorbance was obtained. The response time for optodes with concentration $500 \mathrm{ng} / \mathrm{mL}$, $2000 \mathrm{ng} / \mathrm{mL} \& 5000 \mathrm{ng} / \mathrm{mL}$ is shown in the Figure 2.

\subsection{Linearity Range}

The techniques like spectrophotometer and FAAS were used for linearity studies for the Cd(II) uptake in the developed optode membrane. The optode developed in the present work can be used for the preconcentration of $\mathrm{Cd}(\mathrm{II})$ from aqueous medium, the concentration range and the detection limit for the which optode can be used. The minimum amount of $\mathrm{Cd}(\mathrm{II})$ required to produce detectable response by spectrophotometer is $10 \mathrm{ng} / \mathrm{mL}$. The $\mathrm{R}^{2}$ value for spectrophotometric studies is 0.9642 and the linearity range was shown in the Figure 3. The absorbance

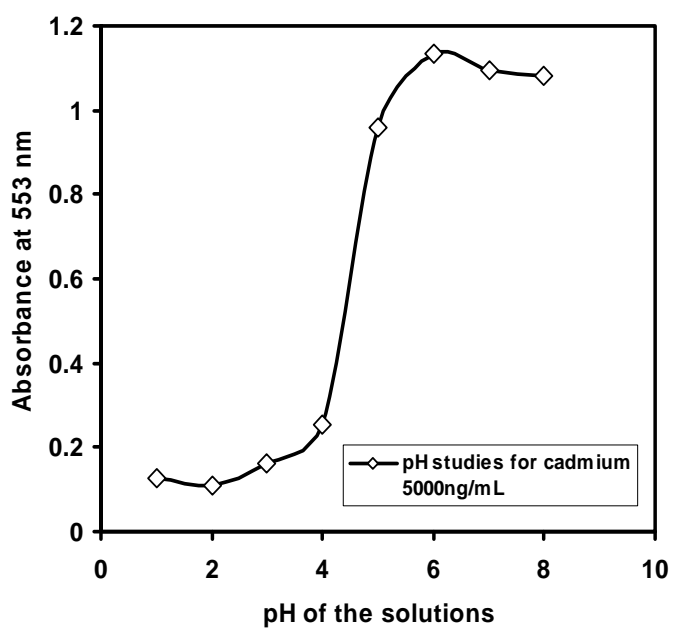

Figure 1. Uptake of $\mathrm{Cd}(\mathrm{II})(5000 \mathrm{ng} / \mathrm{mL})$ in the optode as a function of $\mathbf{p H}$.

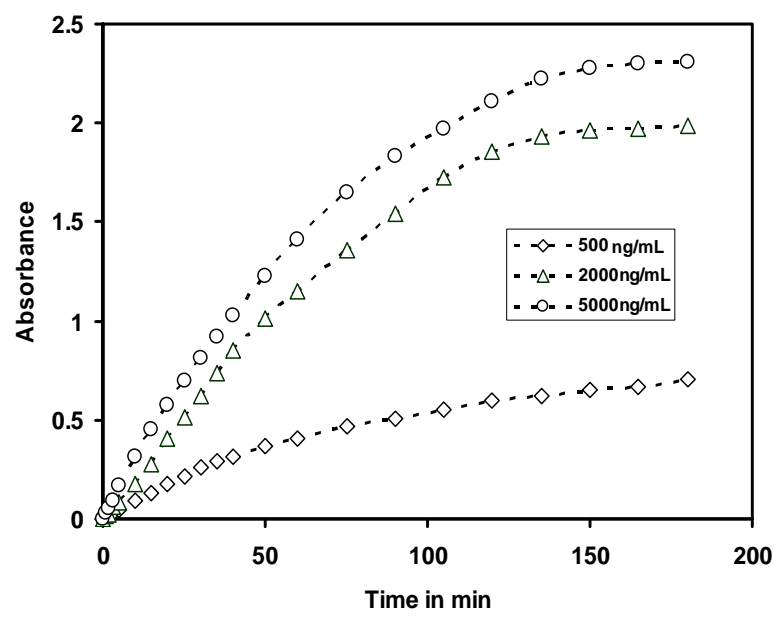

Figure 2. Variation of absorbance of optodes at $553 \mathrm{~nm}$ as function of its equilibration time with different concentations of $\mathrm{Cd}(\mathrm{II})$.

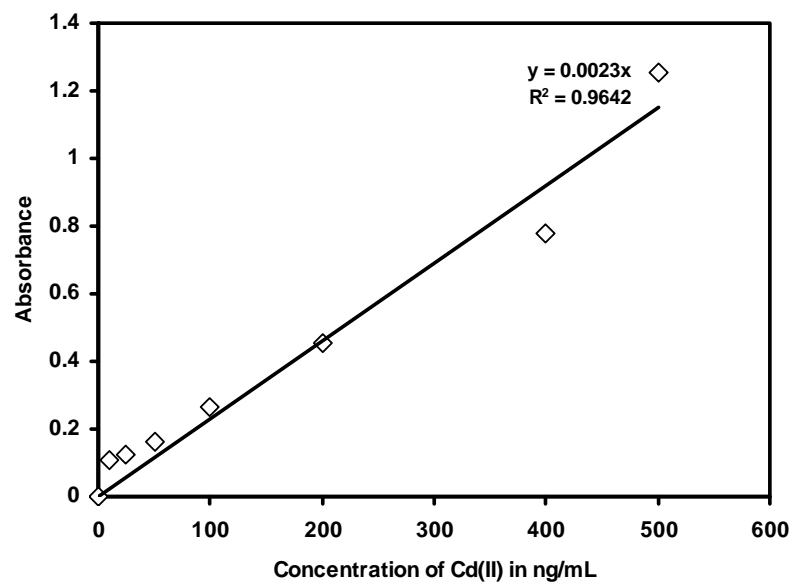

Figure 3. Calibration curve obtained from measurement of the absorbance of optode samples $(2 \mathrm{~cm} \times 1 \mathrm{~cm})$ at $553 \mathrm{~nm}$ by spectrophotometry. 
of the equilibrated optode samples at $553 \mathrm{~nm}$ showed a linear response with a concentration range of $10 \mathrm{ng} / \mathrm{mL}$ to $500 \mathrm{ng} / \mathrm{mL}$ of $\mathrm{Cd}(\mathrm{II})$ by UV-visible spectrophotometry.

The uptake percentage of $\mathrm{Cd}(\mathrm{II})$ by the optode was measured by FAAS making use of before and after equilibrated sample solutions. The quantitative determination of $\mathrm{Cd}(\mathrm{II})$ is dependent upon the volume of the equilibrating solution, the amount of $\mathrm{Cd}(\mathrm{II})$ required in the optode matrix to produce detective response and $\mathrm{Cd}(\mathrm{II})$ sorption capacity of the optode sample by FAAS with $\mathrm{R}^{2}$ $=0.9857$. Detection limit of Cd(II) by FAAS is 250 $\mathrm{ng} / \mathrm{mL}$. In order to study the linear response, water samples of $25 \mathrm{~mL}$ were spiked with known amount of Cd(II) ions and equilibrated with optode sample for $150 \mathrm{~min}$. The absorbance of the before and after equilibrated sample solutions showed a linear response with a range from $250 \mathrm{ng} / \mathrm{mL}$ to $5000 \mathrm{ng} / \mathrm{mL}$. This linear response range by FAAS was shown in the Figure 4.

\subsection{Optode Response}

The UV-Vis absorption spectra of blank and Cd(II) uploaded with various concentrations are given in Figure 5. It was observed that the uncomplexed PAN optode has the maximum absorbance at $\lambda_{\max }=466 \mathrm{~nm}$. It also observed from the same figure with the increase of $\mathrm{Cd}(\mathrm{II})$ concentration the absorption was increased gradually. On complexation with $\mathrm{Cd}(\mathrm{II})$, there was a large banthochromic shift in the absorbance of the optode sample from $466 \mathrm{~nm}$ to $553 \mathrm{~nm}$. On sorption with Cd(II) ions, the optode changes its colour from golden yellow to violet red. The response in the form of increase in absorption at 553 $\mathrm{nm}$, proportional to the amount of cadmium ions preconcentrated in the optode matrix, is generated by the PAN. The change of colour of the optode samples from golden yellow to violet red with the gradual increase in concentration of cadmium ion was shown in the Figure 6.

\subsection{Reproducibility Study}

The reproducibility of the optode was studied by repeating three cycles of $\mathrm{Cd}(\mathrm{II})$ sorption and desorption from the optode sample $(2 \mathrm{~cm} \times 1 \mathrm{~cm})$. For Cd(II) sorption optode was equilibrated in $25 \mathrm{~mL}$ of $1000 \mathrm{ng} / \mathrm{mL}$ of Cd(II) ions for $150 \mathrm{~min}$ and the absorbance was measured at $553 \mathrm{~nm}$. The desorption studies were done by equilibrating the cadmium uploaded optode in $0.01 \mathrm{~N} \mathrm{HNO}_{3}$ aqueous solution with well stirring and the readings were taken for every 2 min till the optode is fully reversible. It was clearly observed that $\mathrm{Cd}$ (II) ions can be quantitatively desorbed within $15 \mathrm{~min}$. The sorption and desorption of $\mathrm{Cd}(\mathrm{II})$ from the optode were studied by monitoring the absorbance at $553 \mathrm{~nm}$. The sorption and desorption

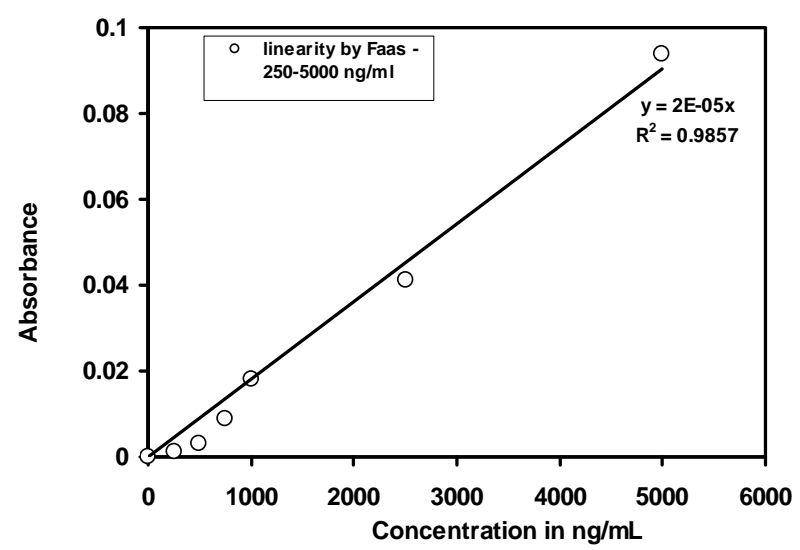

Figure 4. Calibration curve obtained from measurement of the absorbance of equilibrated sample solutions by FAAS.

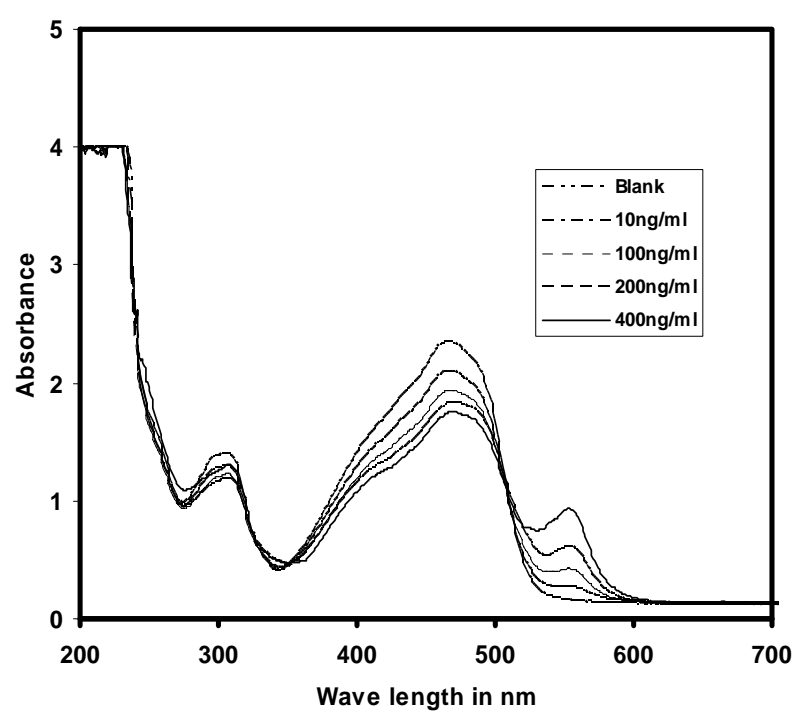

Figure 5. UV-Vis spectra of optode samples spiked with different concentrations of $\mathrm{Cd}(\mathrm{II})$ ions.

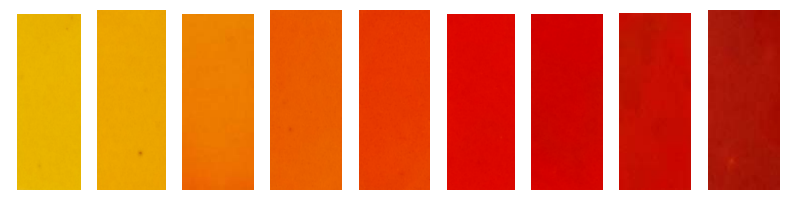

Figure 6. Change in colour of the optodes with different concentrations of $\mathrm{Cd}(\mathrm{II})(10-500 \mathrm{ng} / \mathrm{mL})$.

of $\mathrm{Cd}(\mathrm{II})$ ions profile with three repeated cycles was shown in the Figure 7. It is seen from the figure that the developed membrane optode in the present work is reusable.

\subsection{Interference Studies}

The selectivity for the developed optode was tested for the determination of $\mathrm{Cd}(\mathrm{II})$ in the presence of other foreign anions and cations namely $\mathrm{SO}_{4}^{2-}, \mathrm{PO}_{4}^{3-}, \mathrm{Na}^{+}, \mathrm{Ca}^{2+}$, $\mathrm{Fe}^{3+}, \mathrm{Cr}^{3+}, \mathrm{EDTA}, \mathrm{Mn}^{2+}$ and $\mathrm{Ni}^{2+}$. The various foreign 


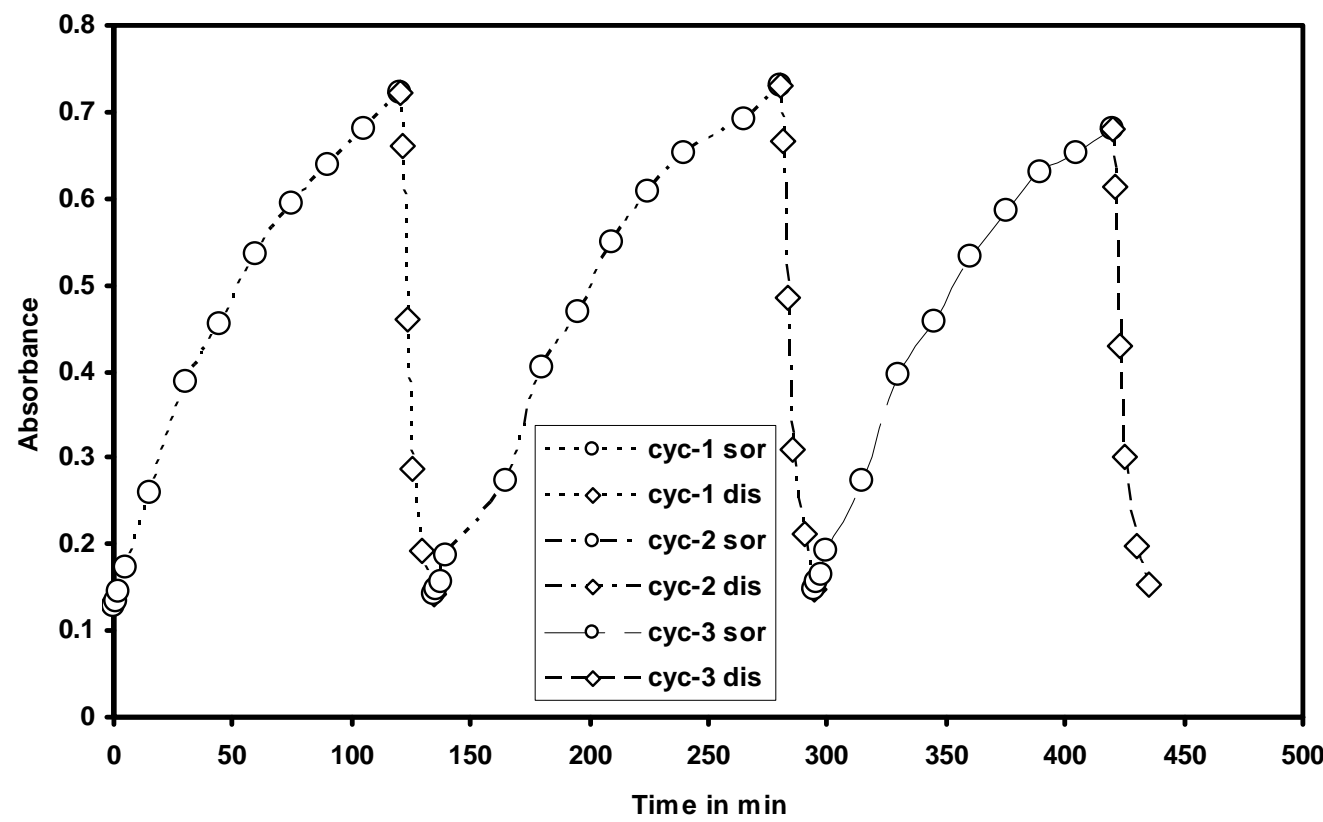

Figure 7. Sorption and desorption cycles of the optode in $25 \mathrm{~mL}$ aqueous solution containing $1000 \mathrm{ng} / \mathrm{mL} \mathrm{of} \mathrm{Cd}(\mathrm{II})$ and 0.01 $\mathrm{mol} \cdot \mathrm{L}^{-1} \mathrm{HNO}_{3}$ respectively.

ions were prepared in $0.01 \mathrm{~mol} \cdot \mathrm{L}^{-1}$ proportion and $2 \mathrm{~cm}$ $\times 1 \mathrm{~cm}$ area optode samples was equilibrated with known amount of $\mathrm{Cd}(\mathrm{II})$ in presence of each interfering ion for $150 \mathrm{~min}$ at $\mathrm{pH}=7.5$. The obtained tolerance limits of the optode in presence of the foreign ions are summarized in Table 1.

\subsection{Analysis of Real Sample}

To evaluate the capability of the membrane optode in the analysis of real water samples, the known amount of metal ion solution is spiked in natural waters $(25 \mathrm{~mL})$. Optode samples was equilibrated with well-stirring for 150 min by adjusting the $\mathrm{pH}=7.5$ and the absorbance was measured at $553 \mathrm{~nm}$. The results of the determination are given in Table 2. From this study it is clearly indicated that the optode prepared in this work can be successfully applied for the determination of $\mathrm{Cd}(\mathrm{II})$ in natural water samples.

\section{Conclusion}

The colour changeable optode for the qualitative and quantitative determination of $\mathrm{Cd}$ (II) ions in aqueous samples was developed by the immobilization of chromopore 1-(2-Pyridylazo)-2-Naphtol (PAN) in the Tri-(2-Ethylhexyl) Phosphate (TEHP) plasticized cellulose triacetate matrix. The developed optode was used to determine $\mathrm{Cd}(\mathrm{II})$ ions in the water samples by using the analytical techniques like spectrophotometer and flame atomic absorption spectroscopy with response with in $150 \mathrm{~min}$. The optode reported in the present work was found to be
Table 1. Tolerance of foreign ions in the determination of Cd(II) (1 mg/L) by spectrophotometry.

\begin{tabular}{ccc}
\hline Sl. No. & Foreign ions & Tolerance [Interferent/Cd(II)] \\
\hline 1 & $\mathrm{SO}_{4}^{2-}, \mathrm{PO}_{4}^{3-}$, & 20 \\
2 & $\mathrm{Na}^{+}, \mathrm{Ca}^{2+}, \mathrm{Fe}^{3+}$, & 15 \\
3 & $\mathrm{Cr}^{3+}, \mathrm{EDTA}$ & 5 \\
4 & $\mathrm{Mn}^{2+}, \mathrm{Ni}^{2+}$ & 2 \\
\hline
\end{tabular}

Table 2. Uptake \% of Cd(II) in the optode from the natural water samples.

\begin{tabular}{cccc}
\hline Samples & $\begin{array}{c}\text { Cd(II) spiked } \\
\text { in } \mathbf{~ m g / L}\end{array}$ & $\begin{array}{c}\text { Cd(II) found } \\
\text { in } \mathbf{~ m g / L}\end{array}$ & $\begin{array}{c}\text { Recovery } \\
\%\end{array}$ \\
\hline Tap water & 1 & $0.99 \pm 0.08$ & 99 \\
Industrial site-1 & 1 & $1.03 \pm 0.09$ & 103 \\
Industrial site-2 & 1 & $0.97 \pm 0.07$ & 97.7 \\
\hline
\end{tabular}

reusable and can be successfully applied for the determination of cadmium in natural water samples.

\section{REFERENCES}

[1] M. Soylak, U. Divrikli, S. Saracoglu and L. Elci, "Membrane Filtration-Atomic Absorption Spectrometry Combination for Copper, Cobalt, Cadmium, Lead and Chromium in Environmental Samples," Environmental Monitoring and Assessment, Vol. 127, No. 1-3, 2007, pp. 169176. doi:10.1007/s10661-006-9271-0

[2] A. Kaur and U. Gupta, "A Preconcentration Procedure Us- 
ing 1-(2-Pyridylazo)-2-Napthol Anchored to Silica Nanoparticle for the Analysis of Cadmium in Different Samples," E-Journal of Chemistry, Vol. 5, No. 4, 2008, pp. 930-939. doi:10.1155/2008/431916

[3] M. Khosravan and A. S. Saljooghi, "Determination of Cadmium by FAAS after Adsorption and Preconcentration on 2-Aminothiophenol Modified Silica Gel," European Journal of Scientific Research, Vol. 48, No. 4, 2011, pp. 606-613.

[4] F. Depault, M. Cojocaru, F. Fortin, S. Chakrabarti and N. Lemieux, "Genotoxic Effects of Chromium(VI) and Cadmium(II) in Human Blood Lymphocytes Using the Electron Microscopy in Situ End-Labeling (EM-ISEL) Assay," Toxicology in Vitro, Vol. 20, No. 4, 2006, pp. 513518. doi:10.1016/j.tiv.2005.09.003

[5] A. C. Davis, P. Wu, X. Zhang, X. Hou and B. T. Jones, "Determination of Cadmium in Biological Samples," Applied Spectroscopy Reviews, Vol. 41, No. 1, 2006, pp. 3575. doi:10.1080/05704920500385486

[6] M. R. Ullah and M. E. Haque, "Spectrophotometric Determination of Toxic Elements (Cadmium) in Aqueous Media," Journal of Chemical Engineering, Vol. 25, No. 1, 2010, pp. 1-12.

[7] M. Jamaluddin Ahmed, M. Salim and J. Bangladesh Acad, "Second Annual Report on Carcinogens," Environmental Protection Agency, NTP 81-43, December 1981, pp. 73-80.

[8] S. J. Haswell, “Atomic Absorption Spectrometry: Theory, Design and Applications," Elsevier, Amsterdam, 1991.

[9] A. Erdem and A. E. Eroglu, "Speciation and Preconcentration of Inorganic Antimony in WATERS by Duolite GT-73 Microcolumn and Determination by Segmented Flow Injection-Hydride Generation Atomic Absorption Spectrometry (SFI-HGAAS)," Talanta, Vol. 68, No. 1, 2005, pp. 86-92. doi:10.1016/j.talanta.2005.04.041

[10] S. L. C. Ferreira, W. N. L. dos Santos, M. A. Bezerra, V. A. Lemos and J. M. Bosque-Sendra, "Use of Factorial Design and Doehlert Matrix for Multivariate Optimisation of an On-Line Preconcentration System for Lead Determination by Flame Atomic Absorption Spectrometry," Analytical and Bioanalytical Chemistry, Vol. 375, No. 3, 2003, pp. 443-449.

[11] A. A. Ensafi and Z. N. Isfahani, "A Simple Optical Sensor for Cadmium Ion Assay in Water Samples Using Spectrophotometry," Journal of Analytical Chemistry, Vol. 66, No. 2, 2011, pp. 151-157. doi:10.1134/S106193481102002X

[12] Y. Kalyan, A. K. Pandey, G. R. K. Naidu and A. V. R. Reddy, "Membrane Optode for Uranium(VI) Ions Preconcentration and Quantification Based on a Synergistic Combination of 4-(2-Thiazolylazo)-Resorcinol with 8Hydroxyquinaldine," Spectrochimica Acta Part A: Mole- cular and Biomolecular, Vol. 74, No. 5, 2009, pp. 12351241. doi:10.1016/j.saa.2009.09.045

[13] A. A. Ensafi, S. Meghdadi and E. Fooladgar, "Development of a New Selective Optical Sensor for Cd(II) Ions Based on 4-Hydroxy Salophen," IEEE Sensor Journal, Vol. 8, No. 11, 2008, pp. 1794-1800. doi:10.1109/JSEN.2008.2005227

[14] C. Sanchez-Pedreno, M. S. Garcia, J. A. Ortuno, M. I. Albero and R. Exposito, "Kinetic Methods for the Determination of Cadmium(II) Based on a Flow-Through Bulk Optode," Talanta, Vol. 56, No. 3, 2002, pp. 481-489. doi:10.1016/S0039-9140(01)00571-9

[15] Y. Kurauchi, R. Hayashi, N. Egashira and K. Ohga, "Fluorometric Determination of Zinc, Cadmium and Gallium Ions with a Fiber-Optic Sensor Having a Pyridoxal Isomer-Modified Chitosan/Agarose Gel as a Sensing Probe," Analytical Sciences, Vol. 8, No. 6, 1992, pp. 837-840. doi:10.2116/analsci.8.837

[16] I. Oehme and O. S. Wolfbeis, "Optical Sensors for Determination of Heavy Metal Ions," Microchimica Acta, Vol. 126, No. 3-4, 1997, pp. 177-192. doi:10.1007/BF01242319

[17] M. Valcarcel and M. D. L. de Castro, "Flow-Through (Bio)chemical Sensors," Elsevier Science, Amsterdam, 1994.

[18] R. Czolk, J. Reichert and H. J. Ache, "An Optical Sensor for the Detection of Heavy Metal Ions," Sensors and Actuators B: Chemical, Vol. 7, No. 1-3, 1992, pp. 540-543. doi:10.1016/0925-4005(92)80360-A

[19] B. Kuswandi, A. A. Vaughan and R. Narayanaswamy, "Simple Regression Model Using an Optode for the Simultaneous Determination of Zinc and Cadmium Mixtures in Aqueous Samples," Analytical Sciences, Vol. 17, No. 1, 2001, pp. 181-186. doi:10.2116/analsci.17.181

[20] B. Rezaei, S. Meghdadi and S. Bagherpour, "Cadmium Selective PVC-Membranes Sensor Based on 1,2-Bis (Quinoline-2-Carboxamido)-4-Chlorobenzene as a Neutral Carrier," Sensors Journal, Vol. 8, No. 8, 2008, pp. 1469-1477. doi:10.1109/JSEN.2008.920719

[21] D. L. Giokas, E. K. Paleologos, M. I. Prodromidis and M. I. Karayannis, "Development of 1-(2-Pyridylazo)-2-Naphthol-Modified Polymeric Membranes for the Effective Batch Pre-Concentration and Determination of Zinc Traces with Flame Atomic Absorption Spectrometry," Talanta, Vol. 56, No. 3, 2002, pp. 491-498. doi:10.1016/S0039-9140(01)00572-0

[22] C. Sanchez-Pedreno, J. A. Ortuno, M. I. Albero, M. S. Garcia and M. V. Valero, "Development of a New Bulk Optode Membrane for the Determination of Mercury(II)," Analytical Chimica Acta, Vol. 414, No. 1-2, 2000, pp. 195-203. doi:10.1016/S0003-2670(00)00809-6 